\title{
Understanding the Factors of Low Employment among Deaf People From the Perspective of Job Coaches
}

Rabeatul Husna Abdull Rahman, Nurfarhanifarah Anuaruddin, Azra Ayue Abdul Rahman, Salwa Abdul Patah, Halimah Mohd Yusof

To Link this Article: http://dx.doi.org/10.6007/IJARBSS/v11-i8/10567

DOI:10.6007/IJARBSS/v11-i8/10567

Received: 12 June 2021, Revised: 14 June 2021, Accepted: 30 July 2021

Published Online: 15 August 2021

In-Text Citation: (Rahman et al., 2021)

To Cite this Article: Rahman, R. H. A., Anuaruddin, N., Rahman, A. A. A., Patah, S. A., \& Yusof, H. M. (2021). Understanding the Factors of Low Employment among Deaf People From the Perspective of Job Coaches. International Journal of Academic Research in Business and Social Sciences, 11(8), 1333-1346.

Copyright: (c) 2021 The Author(s)

Published by Human Resource Management Academic Research Society (www.hrmars.com)

This article is published under the Creative Commons Attribution (CC BY 4.0) license. Anyone may reproduce, distribute, translate and create derivative works of this article (for both commercial and non-commercial purposes), subject to full attribution to the original publication and authors. The full terms of this license may be seen

at: http://creativecommons.org/licences/by/4.0/legalcode

Vol. 11, No. 8, 2021, Pg. 1333 - 1346

Full Terms \& Conditions of access and use can be found at http://hrmars.com/index.php/pages/detail/publication-ethics 


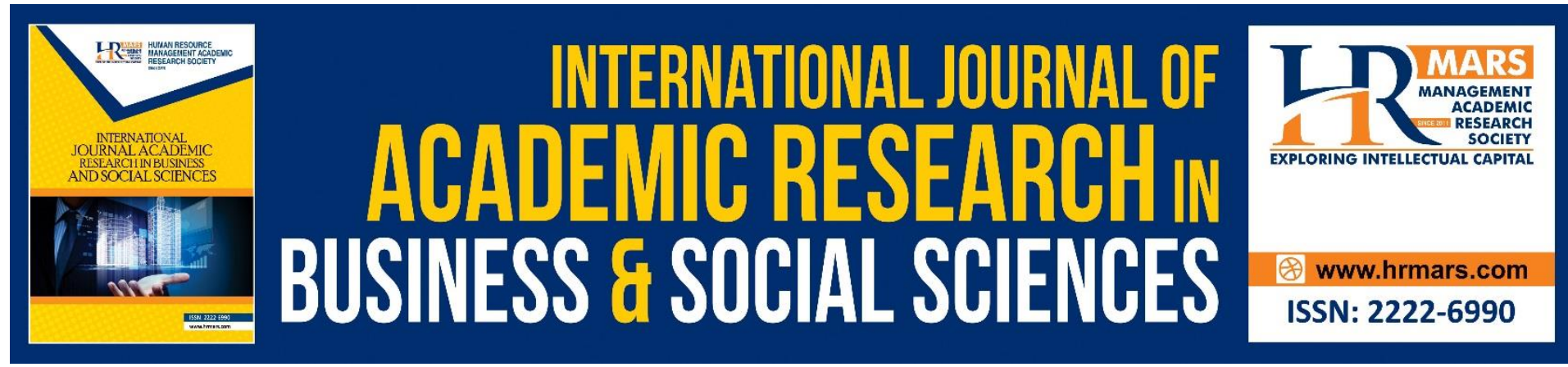

\title{
Understanding the Factors of Low Employment among Deaf People From the Perspective of Job Coaches
}

\author{
Rabeatul Husna Abdull Rahman, Nurfarhanifarah Anuaruddin, \\ Azra Ayue Abdul Rahman, Salwa Abdul Patah, Halimah Mohd \\ Yusof \\ School of HRD and Psychology, Faculty of Social Sciences, Universiti Teknologi Malaysia, \\ 81310 Skudai, Johor, Malaysia \\ Email: rabeatulhusna@utm.my
}

\begin{abstract}
The employment's issues of people with disability (PWD) are not only limited to Malaysia but extend to the global context. Despite introducing the Malaysian Disabilities Act 2008, which entitled PWD for an equal right to access to employment, and various strategies at the national level, the employment rates for PWD are still low. PWDs are often excluded from the mainstream labour market, thence considered as the marginalized group. This research was conducted to explore the factors of low employment among deaf people, particularly in Johor Bahru, Malaysia. Qualitative research design was employed for this study whereby a focus group discussion was conducted with job coaches in a PWD Job Placement Unit and with the president of Deaf Society. The findings revealed several organizational, people and extraorganizational factors that contribute to low employment among deaf people.
\end{abstract}

Keyword: Employability, Employment, People With Disability, Deaf, Disabled

\section{Introduction}

People with disability (PWD) often had to face various struggles in getting employed. Addressing this issue, Lengnick-Hall et.al (2001) argued that despite having the American Disabilities Act 1990, the employment rates for PWD are much lower than for people without disabilities. This data is also true for developing countries such as in India, whereby the labour participation rate for people without disabilities is doubled than for PWD (Powers, 2008). However, it is possible that previous studies on employability of PWD might have been biased (Kaye et.al, 2011). A survey towards Fortune 500 industrial and service corporations in the US has found that over $60 \%$ of the corporations have a recruitment policy tailored for PWD, and over $30 \%$ have, in fact, recruited PWDs within the past three years (Levy et .al, 1992). However, the case may be different in developing countries such as Malaysia, where disability benefit systems are still not in place (Powers, 2008). 
According to World Bank (2005), 80 percent of PWD live in developing countries and they are among the poorest in the developing world. This highlights an urgent need to address this employment issue as it has an implication on the economy and social landscape. It is apparent that the issue of employability of PWD is often discussed with social inclusion. Powers (2008) showed that PWDs are often excluded from the mainstream economic system, and they can be considered as the marginalized population. The result of this exclusion on these PWD is poverty (Yeo, 2005).

Tiun and Khoo (2013) argued that PWD should be included in the mainstream labour market as part of national social development agendas. Besides, past studies have shown evidence that employers have a positive perception towards PWD. In a study by Samian, Md Ali, and Buntat (2013), they found that $80 \%$ of the employers surveyed agreed that PWD demonstrate high initiative, able to accept critiques and are responsible. Besides that, PWD are also said to possess high self-confidence, ability to solve problems, follow instructions, can work under minimal supervision, and are less likely to quit from the job.

However, in the context of Malaysia, although the government has allocated $1 \%$ of job placement for PWD in the public sector, their involvement is still very low. For example, in 2015, the EPU reported that only $0.2 \%$ of PWD were employed in the public sector (EPU, 2015). In other words, the $1 \%$ job placement provided was not able to be filled by PWD. Besides job allocation, the Malaysian government also provides various support programs for PWD through the state agencies such as Job Coach program. Nevertheless, despite these initiatives, the employment rate for PWD is still low in both public and private sectors.

Past studies have mentioned several reasons which may contributes to this scenario. According to a study by Samian, Md Ali, and Buntat (2013), employers commented that PWD are unable to work in teams, and unable to produce quality work as compared to people without disabilities. Since there is a lack of study towards deaf people in Malaysia, hence this study was conducted to explore the factors of low employment among deaf people from the perspective of their job coaches and the representative from the Deaf Society of Malaysia. This study aims to investigate the issues and challenges that deaf people are facing not only in getting employment but also the factors that affects their retention in an organization.

\section{Literature Review}

Based on WHO (2001), the employment of PWD could be explained from two perspectives namely promoting and hindering factors. According to Achterberg et. al (2009), the employment of PWD is promoted by education factor, and hindered by physical barrier factor. Besides physical barrier factor, people and external factors such as environment can also be categorized under the promoting and hindering factors such as individual's social background and experience, as well as the impact of structures, services or system in organization which can bring positive or negative impact on an individual's performance. If the environment does not fit with the individual's health condition, then it will be a restricting factor and barrier to the individual's performance and participation in work (WHO, 2001). Other than severity and type of disability, Artchberg et. al (2012) added that motivation is another important factor of employment among disabled people. 
Previous studies within the Malaysian context have highlighted various factors that can promote and inhibit employment of PWD. According to Tiun \& Khoo (2013) PWD face discrimination and exploitation at work. This is further supported by Khoo, Tiun \& Lee (2013) who indicated that PWD also faced bullying by both private and government sectors. Organizations appear to be treating PWD differently in terms of salary, workload and career advancement. However, between the private sector and government sector, there are more disabled-friendly infrastructures in the private sector (Khoo, Tiun \& Lee, 2013).

Interviews with 24 teachers with visual impairment revealed several causes for low employment; namely employers' negative perception and treatment, employers' lack of confidence, PWD lack of academic skill, negative self-concept, and lack of confidence (Lee, Abdullah \& Mey, 2011). A study on the facilities provided for PWD in an organization shows a low level of provision and a need for improvements of the facilities (Sanmargaraja and Ta Wee, 2011). However, for deaf people, the facility that they need is not in the form of physical structure, but rather in communication form i.e. sign language. Communication barrier has affected the retention of deaf people when the employees of the organization do not understand or know how to use the sign language (Luft, 2000). It is important to understand and solve the issues concerning low employment among deaf people. This is because deaf people are the only disabled people who are accepted to be employed in the small medium enterprises (SME) in Malaysia (Shahari, and Abd Latib, 2006). Employers are found to have positive perception towards deaf people whereby they felt that deaf people have the capacity to perform at the same level as non-disabled people (Johnson. 1993). Their retention however can be influenced by their job satisfaction (Fornes, 2006) driven by high self-determination and people-job congruency.

\section{Research Design}

This study has adopted a qualitative research design whereby data was collected through interviews and focus group discussion. In specific, four job coaches from the PWD Job Placement Unit in Johor Bahru were involved in the focus group discussion. They were asked about their roles as job coaches, the process of job matching, as well as the issues and challenges related to the employment of deaf people. Another separate interview was also conducted with the president of the Deaf Society with the help of a sign language interpreter who was also a job coach. The interview explored about the needs of deaf people and the issues and challenges they face in gaining employment and staying in the job. Data was then analysed using thematic analysis technique.

\section{Findings and Discussion}

The interviews with job coaches and with the president of the Deaf Society revealed several factors that contribute to low employment among deaf people in Johor Bahru. Figure 1 illustrates the findings of this study. 


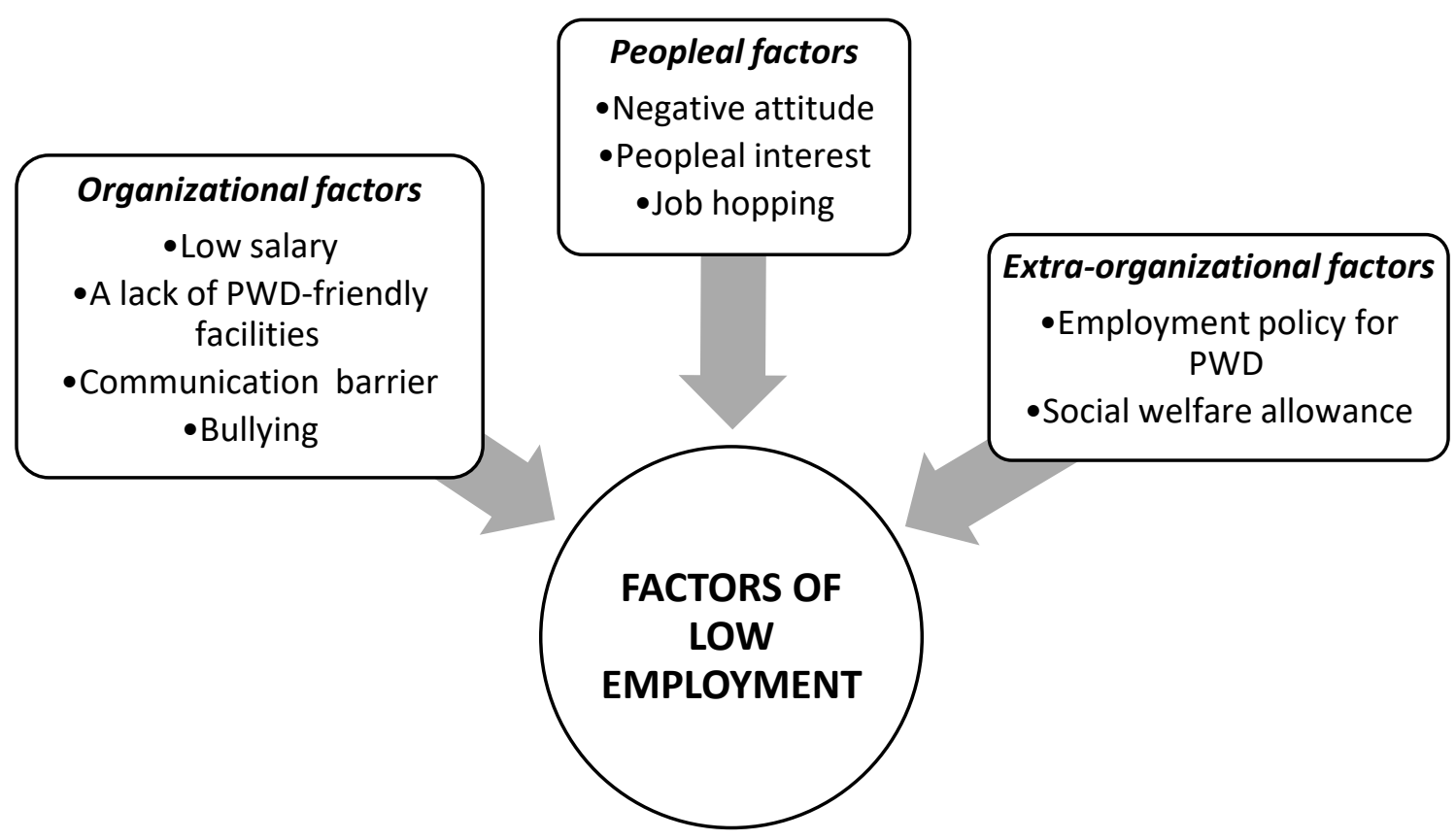

Figure 1: Factors of low employment among PWD Organizational factors

Low Salary

The interview with the president of Deaf Society revealed that deaf people may quit from their jobs due to low salary.

“....salary level has to be equitable ....not just based on job level or position. The best is for employer to provide training or knowledge to them in the first three months of employment. After that, if the employee is interested to continue working, the employer would offer a higher salary. But if they want to quit, we will advise them"

Moreover, the president said that deaf people tend to compare their salary with other friends. They failed to understand that different companies offer different pay rate. He said, "They only see money".

In line with past studies, for instance by Witte, Philips \& Kakela (1998), they found that graduates with learning disabilities are not satisfied with their pay. Tan, Hawkins \& Thomas (1999) have also argued that individuals who are motivated primarily by money are more likely to search for alternative jobs with better pay. This implies a tendency to job hop. On the contrary, Pagán (2013) stated that job satisfaction of disabled workers is mainly influenced by other factors than salary, for instance recognition, support and skills development. Just as this study has found, support may include providing PWD-friendly facilities such as safety infrastructure, conducive accommodation, and transportation.

\section{A lack of PWD-friendly facilities}

The interview with the president of Deaf Society revealed a critical need for deaf people. According to him, organization must be able to provide safety infrastructure as part 
of occupational safety and health practice. This is crucial as most firms uses bell as their fire alert system which obviously is not useful to deaf people.

"If a fire breaks out, or any emergency in the building, there must be a system alerting deaf employees about the incident. For example, a bright light that signifies warning or any other system which could alert deaf employees"

Apart from that, deaf people are also in danger of accident at the workplace since they cannot hear any warning calls from other employees. He recalled his own experience working in a manufacturing factory.

"I was busy and focused in my work using forklift, and I could not hear if anyone shouted 'Move aside!' or 'Danger!'. So, I normally will ask employer to ensure that all moving vehicles, such as forklifts to turn on the lights when being used. For deaf people, we are very sensitive with lights as it 'communicates' (give meaning) to us"

This finding is further supported by one of the job coaches. He said that employers often overlooked the aspect of facilities, such as an emergency system in the toilets.

"If a fire breaks out, and they (deaf people) are in the toilet, how are they supposed to know about it (the fire)? They only see smokes of fires and it may be too late already"

The president further added, "I dare not take the lift by myself" as he felt unsafe. He said, non-disabled people could press the emergency button to communicate verbally, but deaf people communicate using sign language. Moreover, since deaf people are very sensitive to light, it would cause them to panic when there is a blackout in the elevator. He said, "There needs to be a communication tool for deaf people".

Apart from a lack of safety infrastructure in the workplace, deaf people are also concerned about their safety at their hostel. Although some employers provide accommodation for the employees, as reported by the president, they seemed ignorant that deaf people felt uncomfortable sharing rooms with foreign employees.

"Some employers put us together with foreign employees such as from Bangladesh, Nepal, and Vietnam etc. Their way of life is different than us, such as they drink alcohol, so we worry about our safety"

Another PWD-friendly facility that organization can provide is transportation. The interviews with job coaches have revealed that one of the factors for late attendance among PWD is transportation. Similar response was also given by the President, who highlighted that far distance between home and workplace and a lack of transportation may cause deaf people to quit working.

"I suggest that employers hiring PWD to recruit PWD from the local area. Or (for PWD from other areas) employers could provide accommodation or transportation for them to go and return from work. In that way, maybe could solve attendance problem" 
This finding suggests that although deaf people may find employment, the lack of PWD-friendly facilities either in the workplace or at their accommodation may subsequently influence them to leave. It is clear from this finding that safety is very important for deaf people. As per Newton, Ormerod \& Thomas (2007), they highlighted that each disability is unique, and that organization has to ensure that any system that is in place is accessible by many disabilities such as for visual impaired, wheelchair and deaf employees. This is further supported by Bajpai (2015) who revealed that disabled employees have a negative perception that organization is not capable of maintaining safety for disabled employees. This perception may ultimately influence PWDs' intention to work or to continue working.

Tiun \& Khoo (2013) have found that the private sector seemed to be more concerned with the needs of PWD by providing PWD-friendly facilities such as toilets, emergency lighting and others. Tiun \& Khoo (2013) have also highlighted that transportation is indeed a cause of concern for PWD mainly because the country's public transportation system is not only unfriendly but also inaccessible to PWD. Hence PWD relies on their employers to provide transportation facilities.

\section{Communication Barrier}

It is apparent from the interviews with the job coaches that communication is a significant barrier for deaf people. Although deaf people are highly demanded by employer because of their physical capabilities (except hearing), sign language is still uncommon among non-disabled people. Hence there is a communication barrier between deaf people and nondeaf people.

“... for deaf people, (we want our) co-workers such as supervisors, Human Resource, or boss to have the ability to communicate with us using sign language"

According to the president, it is important for the employer or an organization hiring deaf people to have at least someone who have the ability to communicate using sign language. This would enable deaf people to easily raise any issues or problem at work with the person.

\footnotetext{
"Advice has to come from someone expert, not just from the employer....because employer will only offer advice from their perspectives. Expert refers to someone like me, who knows about deaf people, knows about the culture, knows sign language, and able to understand the problem that they are facing. If they inform HR and HR doesn't understand, normally this will not solve the problem. At last, he/she would quit"
}

This finding is consistent with past studies. For instance, as per Luft (2000), the lack of communication support contributed to the unemployment and underemployment of deaf people. As manifested by the Canadian Hearing Society (n.d.) deaf employees can perform their tasks, however, they face several communication challenges at the workplace. This includes a lack of listening devices or computer communications, and an absence of sign language interpreters during meetings, interviews and training programs. 
It is worth noting that the president regards himself as 'an expert who knows about deaf people, the culture...'. This implies that non-deaf people cannot fully understand the predicament that deaf employees are facing. In line with the Canadian Hearing Society (n.d.), it was stated that non-deaf co-workers have a misconception about employees who are deaf or lose their hearing. In a study by Perkins-Dock et.al (2015), it was found that $18.4 \%$ of the employers know little about deafness. Not only the employers expect deaf employees to attend meetings but also if they have difficulty understanding the meetings, they are expected to obtain meeting notes from their fellow colleagues.

\section{Bullying}

Job coaches also mentioned that there are many complaints from deaf people that they have been bullied. Nevertheless, job coaches claimed that bullying is rare and in fact less likely to happen as there is always observation from job coaches and supervisors. Job coaches thus asserted that deaf people are 'too sensitive'. In line with Perry, Hendricks \& Broadbent (2000), they found that disability does not correlate with discrimination. According to Bowe et.al (2005), deaf people are more likely to perceive discrimination than other PWDs. For instance, deaf people may be 'teased' by their co-workers because of their speech patterns voices.

Personal factors

Negative attitude

The interviews with the job coaches revealed several attitudinal problems among deaf people which leads to termination of the job either by the employer or deaf people. These include getting late to work, failure to adhere to working hours, giving too many excuses, and they also tend to decide without consulting job coaches or the employers, such as resigning without giving notice. According to the president of Deaf Society, a lack of accommodation and distance to workplace are among the factors contributing to these negative attitudes.
"Maybe they (deaf employees) feel determined at first, but after sometimes, traveling far to and from work, they will feel tired, and maybe will take MC (medical certificate) the next day or make excuses (to be absent). They could not control which is more important, what they should do"

This suggests that in order to improve the employment of PWD, not only that PWD has to possess the right skills for the job but they also have to demonstrate positive psychological traits such as optimism, confidence, honesty, openness and resilience.

\section{Personal interest}

Job coaches have also mentioned that some deaf people are not interested to work in certain workplaces for instance restaurant, factory or supermarket which further limits their employability. In order to ensure long-term employment, job coaches would try to match deaf people with jobs that satisfy their interests. Nevertheless, according to Baldwin \& Schumacher (2002) it is difficult to find a suitable job match for disabled employees.

On a distinct note, the president of Deaf Society highlighted that deaf people hoped to achieve more in life. 
"The issue is (we) don't want to just be able to survive. Now, it is not about finding food, but we want to live comfortably"

Evidently, deaf people want to be regarded seriously by abled people - they are confident that they are just as capable as abled people, provided that they are given the right facilities to perform at their best. It is obvious that they refuse to be complacent, despite entitled to various benefits, they want to achieve greater heights in life. As mentioned by the job coaches, even PWD with a Master's degree is having difficulty to find a suitable job because of his/her physical disability. This implies that PWD believes they should be treated equally, or at least be given an opportunity to earn a decent living which commensurate with their qualifications.

\section{Job hopping}

According to job coaches, although deaf people are more likely to get employed than other PWDs, they have a higher tendency to job hop too. It is suspected that the availability of alternative jobs may have caused this behaviour. However, as mentioned earlier, the interview with the president of Deaf Society revealed that low salary and a lack of accommodation or transportation problem may also contribute to turnover. According to Baldwin \& Schumacher (2002), disabled employees are more likely to experience involuntary turnover than non-disabled workers. They also argued that disabled employees are unlikely to leave voluntarily. This however, contradicts with the response by job coaches.

\section{Extra-organizational factors}

Employment policy for PWD

According to the president of Deaf Society, it is challenging for deaf people to compete with other non-disabled candidate in getting a job. Although the deaf candidate has equal academic qualification, the candidate could not compete in terms of capability. Thus, the president suggested the following:

"If the government wants to achieve 1\% employment of PWD in the government sector, they have to allocate (1\%) jobs specifically for PWD"

He added on that each PWD is unique in terms of disability which determines their capabilities. Thus, in order to increase PWD employment, the government would have to determine and match jobs with types of disability, such as allocating a certain number of jobs for deaf people, or a certain number or jobs for learning disabled people. In this case it is thus fair for employers to select based on their qualification since they are equal i.e. belong to similar category. He further added that "I think maybe, they (employer/government) say they understand, but I'm not sure whether they really understand about PWD".

\section{Social Welfare Allowance}

One of the benefits for PWD card holders in Malaysia is Disabled Employee Allowance, which entitled eligible PWD to receive MYR350 monthly. However, according to the president of Deaf Society, since the enforcement of minimum salary of MYR1000 for Peninsular Malaysia and MYR920 for Sabah, Sarawak and Federal Territory or Labuan (Attorney General's 
Chambers, 2016), some PWDs are no longer eligible to receive the allowance, which he felt unfair.

"In order to be eligible for the allowance, the PWD has to earn MYR1,200 monthly. Now the minimum salary has been increased to MYR1,000, so if the PWD earns MYR1,300, he/she no longer eligible to receive the allowance. So, the government should increase the limit (so that PWD could still receive the allowance)"

"Even if they earn MYR1,201, they are no longer eligible to receive the allowance. So rightly, (the limit) should be increased. Private companies may not understand this. If let's say, the employee earns basic salary MYR1,100 but he/she's hardworking and do overtime. And if his/her attendance is good, he/she will earn attendance allowance. So, he/she could collect average about MYR1,700-1,800 monthly, maybe MYR2,000. This disqualifies him/her for Disabled Employee Allowance. That allowance (overtime and attendance allowance) is not fixed; it could be taken away anytime. What should be looked at is the basic salary".

The president argument seemed valid especially since the purpose of the allowance is as an incentive to encourage PWD to work, live independently and become a productive society member, as well as to help support daily subsistence and improve the state of life for PWD (JKM, n.d).

\section{Conclusion}

The findings from this study revealed several issues and challenges that are crucial to be addressed in order to improve deaf people participation in the mainstream labour market. It is clear from the findings that salary is one of the factors that discouraged deaf people to seek employment, and has the capacity to influence their intention to continue working in a company. However, increasing their salary would cause another problem; deaf people may no longer be entitled to receive social welfare allowance. So, either the government revises the conditions for the allowance by increasing the limit for basic salary or the employer provides additional allowances or other non-monetary benefits to entice deaf people to find work and to continue working. Non-monetary benefits could be in terms of accommodation which is situated nearby their workplace, or if not, organization could provide transportation facilities.

The lack of safety infrastructure appears to be a major concern not only among the job coaches but also the president of Deaf Society. It is obvious that Malaysian firms are unaware or ignorant of the needs of different PWD. It is understandable that the instalment of safety infrastructure would incur cost on the part of the organization. Unless certain incentives or rebate is awarded to Malaysian firms, it is unlikely for Malaysian firms to play their roles. A positive reinforcement is believed to entice employers more than a negative reinforcement such as enforcement of safety regulations for employers hiring PWD. The latter could demotivate employers from hiring PWD as they perceive them as a burden. 
In particular, for deaf people, they face communication problem since sign language is uncommon among non-disabled people. Aside from that, very little knowledge about deaf people in specific and about other kinds of disabilities not only leads to misconception but also ignorance. The absence of or the very few medium(s) for integration between abled and disabled people has widened the gap between these groups. In the case of deaf people, the inability to communicate using sign language is undeniably one of the key factors that has caused limited interaction. Since deaf people are considered as the most employable compared to other types of PWD, it is timely that sign language be promoted as one of the third languages in Malaysia. Apart from improving interaction, indirectly, communication between abled and deaf people could minimize perceived discrimination or bullying.

Besides organizational and personal factors, extra-organizational factors also contributed to a lower employment among deaf people. In order to increase the participation rate of deaf people in the labour market, the relevant policymakers ought to revise the recruitment policies. The response by the respondents of this study seemed to suggest that matters concerning deaf people in specific, and PWD in general have been overlooked. It is important to acknowledge and understand the different needs of the different disabled group of employees. Only by allocating and customizing jobs for certain disabled category that we could attract PWD and in specific, deaf people to take part in the labour market. Likewise, since deaf people regarded the Social Welfare Allowance as their terminal right, the policymakers might want to revisit the conditions of the allowance so that it does not discriminate rather supports them.

This study contributed to a better understanding of the factors of low employment among deaf. The factors identified from this study has the capacity to help organization to improve themselves as a better employer for deaf people such as by providing safety infrastructure and reducing gaps in communication. This study also served as an eye opener for the authorities to revise the recruitment policies to provide more opportunities for the deaf. Not only that, the deaf themselves also can use these finding to better understand the challenges they might face at the work place. These findings can also be used by the Deaf Society in planning and providing employment support to the deaf such as career counselling, and training courses so that the deaf could manage themselves better at the workplaces.

To conclude, we quote again the response by the president of Deaf Society - 'Now, it is not about finding food, but we want to live comfortably' which not only expressed deaf people's ambition but also hope for a better and brighter future. Although this study could not be generalized, the authors hoped that this research has given some inputs on the factors that have caused low employment among deaf people, and the actions that could be taken by the related stakeholders.

\section{Acknowledgment}

This research has been made possible by the University Grant Program (GUP): Tier 2, (Cost Center Code: Q.J130000.2629.11J74). The researchers would like to extend their gratitude towards Universiti Teknologi Malaysia for funding this study. 


\section{References}

Achterberg, T. J., Wind, H., De Boer, A. G. E. M., and Frings-Dresen, M. H. W. (2009). Factors that promote or hinder young disabled people in work participation: a systematic review. Journal of occupational rehabilitation, 19(2), 129-141.

Achterberg, T. J., Wind, H., and Frings-Dresen, M. H. (2012). What are the most important factors for work participation in the young disabled? An expert view. Disability and rehabilitation, 34(18), 1519-1525.

Attorney General's Chambers. (2016). Minimum Wages Order 2016. P.U. (A) 1162016. Retrieved August 23, 2017, from http://jtksm.mohr.gov.my/images/MPGN/PERINTAH\%20GAJI\%20MINIMUM\%20201 6.pdf

Bajpai, D. (2015). Questionnaire on Factors in Employability of Peoples with Disabilities in India. Retrieved August 23, 2017, from https://papers.ssrn.com/sol3/papers.cfm?abstract_id=2666506

Baldwin, M. L., and Schumacher, E. J. (2002). A note on job mobility among workers with disabilities. Industrial Relations: A Journal of Economy and Society, 41(3), 430-441.

BHOnline. (2017). Jumlah OKU di sektor awam bawah sasaran. Berita Harian Online. Retrieved August 23, 2017, from https://www.bharian.com.my/node/277607

Bowe, F. G., McMahon, B. T., Chang, T., and Louvi, I. (2005). Workplace discrimination, deafness and hearing impairment: The national EEOC ADA research project. Work, 25(1), 19-25.

Canadian Hearing Society (n.d). Breaking The Sound Barriers: Employing People who are Deaf, Deafened or Hard of Hearing. Retrieved August 23, 2017, from https://www.chs.ca/sites/default/files/uploads/breaking_the_sound_barriers.pdf

EPU. (2015). Eleventh Malaysia plan, 2016-2020: Anchoring growth on people. Malaysia: Prime Minister's Department. Retrieved August 23, 2017, from http://epu.gov.my/sites/default/files/Chapter\%203.pdf

Fornes, S. (2006). A Job Retention Model for Individuals with Mental Retardation. Online Submission. Retrieved August 23, 2017, from http://files.eric.ed.gov/fulltext/ED492687.pdf

JKM (n.d.). Syarat dan Kriteria Kelayakan Bantuan Bulanan Kebajikan JKM. Retrieved August 23, 2017, from http://www.jkm.gov.my/jkm/uploads/files/NOTA\%20\%26\%20SYARAT\%20KELAYAKA N\%20BANTUAN\%20BULANAN\%20KEBAJIKAN\%20JKM.pdf.

Johnson, V. A. (1993). Factors impacting the job retention and advancement of workers who are deaf. The Volta Review, 95(4), 341-54.

Kaye, H. S., Jans, L. H., and Jones, E. C. (2011). Why don't employers hire and retain workers with disabilities?. Journal of occupational rehabilitation, 21(4), 526-536.

Khoo, S. L., Tiun, L. T., and Lee, L. W. (2013). Workplace discrimination against Malaysian with disabilities: Living with it or fighting against it?. Disability Studies Quarterly, 33(3).

Lee, M. N., Abdullah, Y., and Mey, S. C. (2011). Employment of People with Disabilities in Malaysia: Drivers and Inhibitors. International Journal of Special Education, 26(1), 112124.

Lengnick-Hall, M. L., Gaunt, P. M., and Brooks, A. A. (2001). Why employers don't hire people with disabilities: A survey of the literature. College of Business, University of Texas at San Antonio. Retrieved August 23, 2017, from http://www.cprf.org/studies/whyemployers-dont-hire-people-with-disabilities-a-survey-of-the-literature/ 
Levy, J. M., Jessop, D. J., Rimmerman, A., and Levy, P. H. (1992). Attitudes of Fortune 500 corporate executives toward the employability of peoples with severe disabilities: $A$ national study. Mental retardation, 30(2), 67.

Luft, P. (2000). Communication barriers for deaf employees: Needs assessment and problemsolving strategies. Work, 14(1), 51-59.

Newton, R., Ormerod, M., and Thomas, P. (2007). Disabled people's experiences in the workplace environment in England. Equal Opportunities International, 26(6), 610-623.

Pagán, R. (2013). Job satisfaction and domains of job satisfaction for older workers with disabilities in Europe. Journal of Happiness Studies, 14(3), 861-891.

Perkins-Dock, R. E., Battle, T. R., Edgerton, J. M., and McNeill, J. N. (2015). A Survey of Barriers to Employment for Individuals Who Are Deaf. Journal of the American Deafness \& Rehabilitation Association (JADARA), 49(2), 66-85.

Perry, E. L., Hendricks, W., and Broadbent, E. (2000). An exploration of access and treatment discrimination and job satisfaction among college graduates with and without physical disabilities. Human Relations, 53(7), 923-955.

Powers, T. (2008). Recognizing ability: The skills and productivity of peoples with disabilities. Literature review. Switzerland: International Labour Office, Geneva.

Sanmargaraja, S., and Ta Wee, S. (2011) Kajian penyediaan fasiliti orang kurang upaya (OKU) di institusi kerajaan di Nusajaya, Johor Bahru. In: Kertas kerja Persidangan Kebangsaan Geografi dan Alam Sekitar kali ke 3. Universiti Pendidikan Sultan Idris, Tanjong Malim. Retrieved August 23, 2017, from http://eprints.uthm.edu.my/2027/1/Seow_Ta_Wee_FPTPK_(PKGAS).pdf

Shahari, R., and Abd Latib, A. (2006). Tanggapan Usahawan Industri Kecil Dan Sederhana (iks) kerepek Ubi Dan Pisang Di Sekitar Batu Pahat Terhadap kemampuan Golongan Orang Kurang Upaya (oku) Untuk bekerja Dalam Industri Mereka. Doctoral dissertation. Universiti Teknologi Malaysia.

Samian, S. S., Ali, M. K., and Buntat, Y. (2013). Persepsi majikan terhadap pekerja orang kurang upaya (OKU) dalam organisasi di Negeri Johor. 2nd International Seminar on Quality and Affordable Education (ISQAE 2013). Johor Bahru, 349.

Tan, P. P., Hawkins, W. E., and Thomas, L. (1999). Job satisfaction and intent to continue working among individuals with serious mental illness. Psychological reports, 85(3), 801-807.

Tiun, L. T., and Khoo, S. L. (2013). Challenges faced by Malaysian with disabilities in the world of employment. Disability, CBR \& Inclusive Development, 24(1), 6-21.

Utusan Online. (2016). OKU terkilan JKM potong elaun RM350. Utusan Online. Retrieved August 23, 2017, from http://www.utusan.com.my/berita/nasional/oku-terkilan-jkmpotong-elaun-rm350-1.344227.

WHO. (2001). International classification of functioning, disability and health. Geneva: World Health Organization. Retrieved August 23, 2017, from http://apps.who.int/iris/bitstream/10665/42407/1/9241545429.pdf

Witte, R. H., Philips, L., and Kakela, M. (1998). Job satisfaction of college graduates with learning disabilities. Journal of learning disabilities, 31(3), 259-265.

World Bank. (2005). Development outreach: Disability and inclusive development. Washington, DC: World Bank. Retrieved August 23, 2017, from http://documents.worldbank.org/curated/en/805041468314726419/pdf/4062010co lor.pdf 
INTERNATIONAL JOURNAL OF ACADEMIC RESEARCH IN BUSINESS AND SOCIAL SCIENCES

Vol. 11, No. 8, 2021, E-ISSN: 2222-6990 @ 2021 HRMARS

Yeo, R. (2005). Disability, poverty and the new development agenda. Disability Knowledge and Research. 133. Retrieved August 23, 2017, from

https://assets.publishing.service.gov.uk/media/57a08c52ed915d3cfd0012f2/RedPov _agenda.pdf 